\title{
Non-financial Reporting in the System of Increasing Corporate Transparency of Russian Business
}

\author{
Svetlana Grishkina \\ Financial University under the Government of the Russian Federation \\ Moscow, Russia \\ E-mail: sgrishkina@list.ru
}

\author{
Vera Sidneva \\ Financial University under the Government of the Russian \\ Federation \\ Moscow, Russia \\ E-mail: v.sidneva@gmail.com
}

\author{
Galina Dubinina \\ Financial University under the Government of the Russian \\ Federation \\ Moscow, Russia \\ E-mail: GADubinina@fa.ru
}

\begin{abstract}
The article deals with the development of the institute of non-financial reporting. Non-financial reporting is designed to improve the transparency of Russian business, it contains information about economic, environmental and social aspects of a company performance. The need to assess sustainable development at an economic entity level led to the emergence of new requirements for the formation and presentation of corporate reports: companies must inform stakeholders on three interrelated aspects of their activitieseconomic, environmental and social. Thus, activities in the field of corporate social responsibility (CSR) and sustainable development should be systemic in nature.
\end{abstract}

Keywords-non-financial reporting; corporate social responsibility; sustainable development; sustainable development concept; development of public non-financial reporting concept; directive on the disclosure of non-financial information

\section{INTRODUCTION}

Increasing transparency of Russian business in recent years has been associated with the development of the Institute of non-financial reporting. Its appearance in the world is associated with the development and application of a balanced scorecard (BSC). As its authors (R. Kaplan and D. Norton, the recognized architects of the system), rightly point out, "financial performance is not sufficient to assess the performance of an enterprise during the information age, when companies must increase their future value through consumers, suppliers, their employees, new technologies and innovations" [1]. The corporate non-financial reporting landscape has been decisively shaped by BSC. As some modern scholars indicate, the BSC strength is in integrating such non-financial metrics as customer, internal processes, learning and growth with the traditional financial metrics [2]. The demand from various stakeholders for credibility and transparency resulted in recent developments in relation to various reporting guidelines and standards.

\section{HISTORICAL ASPECTS OF NON-FINANCIAL REPORTING IN INTERNATIONAL AND DOMESTIC PRACTICE DEVELOPMENT}

There is much overlap between the terms "corporate social responsibility" and "sustainability". Consequently, they are usually used synonymously [3]. Non-financial reporting refers to documents officially published by companies and organizations in which they provide stakeholders with a full range or a limited number of aspects of their activity in the field of responsible business practices, corporate social responsibility (CSR) or sustainable development (SD). Such documents include information about CSR strategy in conjunction with company's development strategy, ethical business principles, the quality of corporate governance, contribution to environmental and human rights protection, Human Resource management, quality of products and services, support of local communities, company's impact on society in all key areas of its activity [4].

The history of non-financial reporting begins in the 1970 s, at first it performed an advertising function, and only in the 1990s there shaped a vision that activity in the field of corporate social responsibility (CSR) and sustainable development should be systemic in nature and managed in the same way as other business processes.

At the same time the most important internal function of non-financial reports was defined as being a tool for planning and evaluating the performance of a business in the long run.

The concept of corporate social responsibility (CSR) began to take shape in developed countries with financial stability around the middle of the last century and was mainly focused on the regulation of charitable activities of companies. CSR theory was put forward by scientists and 
researchers, and then tested by companies that made attempts to apply it in their own business practice.

The wide introduction of corporate responsibility elements into the corporate governance practice began in the 1970s, when labour relations and fair business practices began to be attributed to CSR aspects. Such aspects as human rights, environmental issues, consumer protection, anti-fraud and anti-corruption were added over time as they draw more and more attention.

In 1987, in its report "Our Common Future", the World Commission on Environment and Development (WCED), drew attention to the need for "sustainable development", in which "meeting the needs of the present without compromising the ability of future generations to meet their own needs ".
The concept of sustainable development covers different levels: planetary, national, sectoral, as well as that of the economic entity. Different approaches are proposed by theorists and practitioners to measure the sustainability of each level. The need to assess sustainable development at the level of an economic entity led to the emergence of new requirements for the compilation and presentation of corporate reports: companies must inform interested users on three interrelated aspects of their activities: economic, environmental and social. There appeared a new modification of non-financial reporting: sustainable development reporting.

"Table I" presents the main stages of non-financial reporting development in international and domestic practice, including reporting on sustainable development.

TABLE I. MAIN Stages of NON-FINANCIAL REPORTING DEVELOPMENT

\begin{tabular}{|c|c|}
\hline Period & Documents adopted and Creation of Organization \\
\hline 1997 г. & Global Reporting Initiative (GRI) - international independent organization \\
\hline 2000 г. & $\begin{array}{l}\text { The first version of the "Sustainability Reporting Guidelines" } \\
\text { GRI (G1) }\end{array}$ \\
\hline 2002 г. & The Second version of the "Sustainability Reporting Guidelines " GRI (G2) \\
\hline 2004 г. & $\begin{array}{l}\text { "Social Charter of Russian business", adopted by the Congress of the Russian Union of Industrialists } \\
\text { and Entrepreneurs (RSPP), published in } 2005\end{array}$ \\
\hline 2006 г. & The Third version of the GRI "Sustainability Reporting Guidelines" (G3) [5] \\
\hline 2008 г. & The UN Global compact Network was founded in the Russian Federation \\
\hline 2010 г. & ISO 26000: 2010 “Guidance on social responsibility”) [6] \\
\hline 2011 г. & $\begin{array}{l}\text { Recommendations on self-assessment of company's activities in accordance with the principles of } \\
\text { social responsibility based on the provisions of the international standard ISO 26000:2010 "Guidelines } \\
\text { on social responsibility" (RSPP in December 2011) were approved }\end{array}$ \\
\hline 2012 г. & $\begin{array}{l}\text { National standard "Guide to social responsibility" GOST R ISO 26000:2012 (order of the Federal } \\
\text { Agency for Technical Regulation and Metrology of November 29, 2012 № 1611-C was approved }\end{array}$ \\
\hline 2012 г. & The Council for standardization of sustainable development reporting was founded (SASB) \\
\hline 2013 г. & Fourth version of the GRI (G4) "Sustainability Reporting Guidelines" [7] [8] \\
\hline 2017 г. & $\begin{array}{l}\text { Concept of public non-financial reporting (Order of the Government of the Russian Federation of May } \\
5,2017 \text { N 876-p) was approved [9] }\end{array}$ \\
\hline
\end{tabular}

The GRI reporting framework remains the most widely used standard for sustainability reporting. In recent years, the number of companies using the GRI Guidelines has increased by between 300 to 500 each year [10].

Economic literature offers a wide range of analysis on the development of the institute of non-financial reporting in the international world as well as in the Russian Federation [11] [12] [13]. In recent years, the challenges of generating and presenting non-financial reporting, including sustainable development reporting and integrated reporting, have been discussed at various venues: conferences, forums, round tables, etc.

The trend of disclosing non-financial information continues its upward trajectory worldwide. However, the compilation and publication of non-financial statements is a voluntary business initiative. In a number of countries, such as France, Norway, Denmark, Sweden, Finland, the Netherlands, state-owned companies are obliged to report on the results of their activities in specific areas and indicators of corporate social responsibility. In South Africa, all companies listed on the Johannesburg stock exchange must prepare integrated reporting (financial and non-financial).
The ratio of countries that have mandatory requirements for the disclosure of non - financial information and countries where voluntary initiatives are in force is constantly changing towards mandatory disclosure: in 2006, this ratio was 58 by $42 \%$, in $2010-62$ by $38 \%$, and in $2013-$ 72 by $28 \%$ [14].

Currently, thirty of the fifty largest countries in the world have introduced non-financial reporting requirements, and over the past three years, sixty-four countries have introduced a few non-financial reporting instruments [15].

\section{STANDARDIZATION OF COMPILING NON-FINANCIAL REPORTING}

In the EU Member States, the Directive on disclosure of non - financial information has been in effect since the end of 2014, with the aim of increasing the transparency of large EU companies. The Directive obliges companies of interest to the society with more than 500 employees to disclose nonfinancial information [16]. In this case, companies of interest to the society comprise listed companies that trade in the EU markets, as well as some non-listed, such as credit organizations, insurance companies and other enterprises, 
defined by Member States in view of their activities, size or number of staff.

In accordance with article 4 of EU Directive 2014/95/EU on non-financial disclosure, Member States are to ensure that these provisions apply to all enterprises in the financial year beginning on 1 January 2017 or during the 2017 calendar year [17].

Since the adoption of the Directive all EU Member States have transferred these rules into their national legislation, which led to the emergence of a number of innovative and progressive practices [18].

The Directive requires that the non-financial report describes the current business model, the company's policy on the implementation of the principles of social responsibility and sustainable development, the procedure for the implementation of the due diligence process, the results of the introduction of new policies, as well as significant risks related to the company's activities in the field of sustainable development.

The directive provides a high degree of flexibility in the use of various standards and guidelines by companies in the preparation of non-financial reports. The Directive signposts a rout towards greater business transparency and accountability on social and environmental issues. Besides, national standards, recommendations, manuals can be used along with pan-European ones.

In practice, when preparing non-financial reports, companies most often adhere to the requirements of the International Standard ISO 26000: 2010 "Guidelines for Social Responsibility" and "Guidelines for Reporting in the Field of Sustainable Development" (GRI). Some companies apply several standards and guidelines simultaneously in "Table II".

TABLE II. APPLICATION OF STANDARDS AND GUIDELINES IN THE PREPARATION OF NON-FINANCIAL STATEMENTS OF RUSSIAN COMPANIES

\begin{tabular}{|l|l|l|l|}
\hline \multirow{2}{*}{ Reporting systems } & \multicolumn{2}{|c|}{ Number of reports prepared by using: } \\
\cline { 2 - 4 } & $\begin{array}{c}\text { One reporting } \\
\text { system }\end{array}$ & \multicolumn{1}{c|}{$\begin{array}{c}\text { Three or mopore } \\
\text { systems }\end{array}$} & \multicolumn{1}{c|}{ reporting systems } \\
\hline GRI (G3 и G4) & 30 & 13 & 22 \\
\hline AA 1000 & 1 & - & 4 \\
\hline $\begin{array}{l}\text { Social Charter and basic performance } \\
\text { indicators RSPP }\end{array}$ & & - & 15 \\
\hline ISO 26000 & - & - & 7 \\
\hline The UN Global Compact & - & - & 7 \\
\hline Guide to integrated reporting IIRC & - & - & 7 \\
\hline Corporate public reporting standards & - & - & 7 \\
\hline Rosatom State Corporation & - & - & 1 \\
\hline $\begin{array}{l}\text { Guide to reporting for companies in the oil } \\
\text { and gas industry (IPIECA) }\end{array}$ & - & & - \\
\hline Other systems & - & 13 & 7 \\
\hline
\end{tabular}

The development of non-financial reporting in the Russian Federation is closely related to the activities of the Russian Union of Industrialists and Entrepreneurs aimed at making Russian business more transparent.

Russian Union of Industrialists and Entrepreneurs pays great attention to verification (certification, confirmation) of non-financial reports and forms the national Register of corporate non-financial reports (data bank of voluntary nonfinancial reports of organizations operating in the Russian Federation) [20]. The national Register includes a register of companies that issue non-financial reports (sustainability reports, social reports, environmental reports, integrated reports, industry reports), as well as a Library of NonFinancial Reports that contains electronic versions of officially published non-financial reports of companies operating in Russia, as well as some large multinational companies.

As of May 7, 2018, 167 companies were included in the National Register of Non - Financial Reports, 826 reports were registered (issued in the period since 2000), including: environmental reports (EO) - 73, social reports $(\mathrm{CO})-311$, reports on sustainable development (ESD) - 277, integrated reports - 141, industry reports-26 [21]. Leaders in the number of reports are: energy sector (42 companies); oil and gas industry (42 companies), metallurgical and mining (19 companies); financial sector (18 companies).

Independent evaluation is an important factor in improving the quality of reporting information, gives stakeholders greater confidence in the accuracy of the data, reduces the risk of inaccurate interpretations and contradictions.

Various world organizations provide external assurance services for non-financial reports: audit companies of the "big four", other professional organizations working in the field of audit and certification, management consulting, public organizations. "Stakeholder assurance" is also used, i.e. certification by a group of individuals representing the company's stakeholders.

Obviously, it is audit firms that should certify information relating to the financial performance of companies. In other cases, external certification may be carried out by other organizations or individuals. The GRI system envisages that verifiers should be competent in the field of non-financial reporting, external to the company whose report undergoes certification, to apply a professional 
approach to certification, as well as systematic, documented, based on the actual data processes [22].

\section{INTRODUCTION OF MANDATORY DISCLOSURE OF NON-FINANCIAL REPORTING IN RUSSIA}

The use of international practice of strengthening the requirements for disclosure of non-financial information, i.e. the introduction of mandatory rules at the legislative level, will help to increase corporate transparency of Russian companies.

The first step towards the adoption of legislative requirements was the Government of the Russian Federation approval of the Concept for the Development of Public NonFinancial Reporting [23]. It is planned to gradually introduce requirements to socially significant companies for the publication of non-financial statements, create legal regulation in the field of non-public financial statements, as well as the formation of mechanisms aimed at stimulating its preparation and certification.

In the future the Federal law "On public non-financial reporting" is supposed to be adopted, whose draft contains requirements for information on the activities of companies in the field of social and corporate relations, environment, and labor protection [24]. Currently, the draft law is freely available for public discussion on the website of the Ministry for Economic Development of the Russian Federation.

The draft provides for mandatory disclosure of nonfinancial statements for the largest Russian companies and state corporations, it contains provisions for information and indicators in the field of prevention of corruption to be included in public non-financial reporting.

\section{CONCLUSION}

Taking into account the current conditions, the new law will contain definitions of non-financial reports: a report on sustainable development activities, an integrated report, a report on preventing corruption. It is assumed that the mandatory requirement to prepare public non-financial statements at the end of 2019 will be applied to state-owned enterprises and companies with a state share of more than $50 \%$, whose revenue or assets exceed 10 billion rubles. Since 2021, it will be mandatory to disclose non-financial statements of companies whose shares are listed on the exchanges and included in their quotation lists.

\section{REFERENCES}

[1] R.S. Kaplan, D.R Norton, "The Balanced Scorecard: Translating Strategy into Action, Boston: HBS Press, $1996-321$ p.

[2] E.A. Awadallah, A. Allam. A Critique of the Balanced Scorecard as a Performance Measurement Tool. // International Journal of Business and Social Science, Vol.6, No, 7; July 2015. URL: http://www.ijbssnet.com/journals/Vol_6_No_7_July_2015/9.pdf

[3] Targeting Transparency 2016. URL http://www.ey.com/Publication/vwLUAssets/ey-targetingtransparency-2016-edition/\$FILE/ey-targeting-transparency-2016edition.pdf
[4] L. V. Alenicheva, E. N. Feoktistova, N. V. Khonyakova, M. N. Ozeryanskaya, G. A. Kopylova, Responsible business practices in the reporting mirror. Analytical review of corporate non-financial reports: 2012-2014. Moscow: RSPP, 2015. - 136 p.

[5] GOST R ISO 26000-2012. National Standard of the Russian Federation. Guide to Social Responsibility (app. and promulgated by the Order of Rosstandart on 29.11.2012 No. 1611-St) // ATP ConsultantPlus.

[6] Russian-Reporting-Guidelines GRI-G3. Available online: https://www.globalreporting.org/resourcelibrary/GRI-G3-RussianReporting-Guidelines.pdf

[7] Sustainability Reporting Guidelines G4. Available online: http://media.rspp.ru/document/1/e/6/e6aef2d23c03d8181b6230003f97 7361.pdf

[8] Guidance to the Sustainability Reporting Guidelines G4 Available online:

http://media.rspp.ru/document/1/e/6/e6aef2d23c03d8181b6230003f97 7361.pdf

[9] Order of the Government of the Russian Federation of 05.05.2017 N 876-r "On approval of the Concept for the Development of Public Non-Financial Reporting and Action Plan for its Implementation" ATP ConsultantPlus.

[10] Targeting Transparency $2016 . \quad$ URL: http://www.ey.com/Publication/vwLUAssets/ey-targetingtransparency-2016-edition/\$FILE/ey-targeting-transparency-2016edition.pdf Available online: https://government.consultant.ru/documents/3717616

[11] S. N. Grishkina, Problems of financial, management and statistical accounting in agriculture (monograph). M.: Financial University, 2012. - 140 p.

[12] S. N. Grishkina, V. P. Sidneva, Problems of formation and disclosure of information on the social responsibility of agricultural business // Economics and management: problems, solutions. - 2015. \# 3 (53), pp. 39-45.

[13] S. N., Grishkina, V. P. Sidneva, The formation and disclosure of information about sustainable development agricultural business // proceedings of the Orenburg State Agrarian University. 2014. No. 5, pp. 210-212.

[14] L. V. Alenicheva, E. N. Feoktistova, N. V. Khonyakova, M. N. Ozeryanskaya, G. A. Kopylova, Responsible business practices in the reporting mirror. Analytical review of corporate non-financial reports: 2012-2014, Moscow: RSPP, 2015, 136 p.

[15] E.N. Feoktistova, L.V. Alenicheva, E.I. Dolgikh, G.A. Kopylova, M.N. Ozeryanskaya, N.V. Khonyakova, Analytical review of corporate non-financial reports: 2015-2016. - Moscow: RSPP, 2017. $136 \mathrm{p}$.

[16] E.N. Feoktistova, L.V. Alenicheva, E.I. Dolgikh, G.A. Kopylova, M.N. Ozeryanskaya, N.V. Khonyakova, Analytical review of corporate non-financial reports: 2015-2016. - Moscow: RSPP, 2017. $136 \mathrm{p}$.

[17] Directive on the disclosure of non-financial and diversity information by certain large undertakings and groups (Directive 2014/95/EU). Available online: http://csrjournal.com/17611-direktiva-es-poraskrytiyu-nefinansovoj-informacii-vse-chto-vy-xoteli-sprosit.html

[18] Innovative implementation of EU Directive on Non-Financial $\begin{array}{llll}\text { Reporting } & 07 & \text { February } 2018 . & \text { URL: }\end{array}$ https://www.globalreporting.org/information/news-and-presscenter/Pages/EU-Directive-on-Non-Financial-Reporting.aspx

[19] E.N. Feoktistova, L.V. Alenicheva, E.I. Dolgikh, G.A. Kopylova, M.N. Ozeryanskaya, N.V. Khonyakova, Analytical review of corporate non-financial reports: 2015-2016. - Moscow: RSPP, 2017. p. 20.

[20] National register and library of corporate non-financial reports. URL: http://pcпп.pф/simplepage/157 (Access 13.05.2018).

[21] National register and library of corporate non-financial reports. URL: http://pcпп.pф/simplepage/157 (Access 13.05.2018).

[22] L. V. Alenicheva, E. N. Feoktistova, N. V. Khonyakova, M. N. Ozeryanskaya, G. A. Kopylova, Responsible business practices in the 
reporting mirror. Analytical review of corporate non-financial reports: 2012-2014. Moscow: RSPP, 2015. 136 p.

[23] Order of the Government of the Russian Federation of 05.05.2017 N 876-r "On approval of the Concept for the Development of Public Non-Financial Reporting and Action Plan for its Implementation" ATP ConsultantPlus. Available online: https://government.consultant.ru/documents/3717616

[24] Draft Federal law "on public non-financial reporting" (prepared by the Ministry of economic development of Russia) (not included in the state Duma of the Russian Federation, the text as of 28.12.2017) // ATP consultant. 